\title{
Correction to: The dissemination of relevant information on wildlife utilization and its connection with the illegal trade in wildlife
}

\author{
Zhifan Song $^{1}$ - Qiang Wang ${ }^{2}$ Zhen Miao ${ }^{1}$. \\ Wei Zhang ${ }^{1} \cdot$ Xuehong Zhou ${ }^{1}$
}

Published online: 17 April 2021

(C) The Author(s) 2021

\section{Correction to:}

\section{J. For. Res. https://doi.org/10.1007/s11676-021- 01306-y}

The article "The dissemination of relevant information on wildlife utilization and its connection with the illegal trade in wildlife", written by Zhifan Song · Qiang Wang · Zhen Miao- Wei Zhang and Xuehong Zhou, was originally published electronically on the publisher's internet portal on 11th March 2021 without open access. With the author(s)' decision to opt for Open Choice the copyright of the article changed on 16th March 2021 to (C) The Author(s) 2021 and

The original article can be found online at https://doi.org/10. 1007/s11676-021-01306-y.

Wei Zhang

zwfur_nefu@126.com

$\triangle$ Xuehong Zhou

xuehong_zhou2012@126.com

1 College of Wildlife and Protected Area, Northeast Forestry University, Harbin 150040, People's Republic of China

2 Key Laboratory of Wetland Ecology and Environment, Northeast Institute of Geography and Agroecology, Chinese Academy of Sciences, Changchun 130102, People's Republic of China the article is forthwith distributed under a Creative Commons Attribution 4.0 International License (https://creat ivecommons.org/licenses/by/4.0/), which permits use, sharing, adaptation, distribution and reproduction in any medium or format, as long as you give appropriate credit to the original author(s) and the source, provide a link to the Creative Commons licence, and indicate if changes were made. The original article has been corrected.

The original article has been corrected.

Open Access This article is licensed under a Creative Commons Attribution 4.0 International License, which permits use, sharing, adaptation, distribution and reproduction in any medium or format, as long as you give appropriate credit to the original author(s) and the source, provide a link to the Creative Commons licence, and indicate if changes were made. The images or other third party material in this article are included in the article's Creative Commons licence, unless indicated otherwise in a credit line to the material. If material is not included in the article's Creative Commons licence and your intended use is not permitted by statutory regulation or exceeds the permitted use, you will need to obtain permission directly from the copyright holder. To view a copy of this licence, visit http://creativecommons.org/licenses/by/4.0/.

Publisher's Note Springer Nature remains neutral with regard to jurisdictional claims in published maps and institutional affiliations. 